$\begin{array}{lll}\mathbf{Z} & \mathbf{P} \\ \\ \\ & \text { Mitosz SOSNOWSKI } \\ \text { Uniwersytet Warszawski }\end{array}$

\title{
Miejsce powstania i historia pasjonalu theol. lat. oct. 162 ze zbiorów Biblioteki Państwowej w Berlinie*
}

Zarys treści: Artykuł poświęcony jest pochodzeniu i historii kodeksu ze zbiorów Biblioteki Państwowej w Berlinie, opatrzonego sygnaturą theol. lat. oct. 162. Kodeks ten zawiera jedyną znaną kopię Vita Quinque Fratrum autorstwa Brunona z Kwerfurtu. Druga częś pracy poświęcona jest próbie rekonstrukcji drogi, za sprawą której tekst znalazł się w bibliotece klasztornej w Huysburgu.

Abstract: The article deals with the origin and history of a codex from the collections of the Berlin State Library (call no. theol. lat. oct. 162). The codex contains the only known copy of Vita Quinque Fratrum by Bruno of Querfurt. The second part of the article aims at reconstruction of the history of the text itself before the aquisition of the copy by the Huysburg abbey library.

Słowa kluczowe: Brunon z Kwerfurtu, Pięciu Braci Męczenników, kodykologia, paleografia, theol. lat. oct. 162, Huysburg, skryptorium, Biblioteka Państwowa w Berlinie, hagiografia,

Keywords: Bruno of Querfurt, Five Brothers, codicology, palaeography, theol. lat. oct. 162, Huysburg, scriptorium, Staatsbibliothek Berlin, hagiography

„Nie udało się dotąd znaleźć miejsca powstania ani prześledzić dziejów rękopisu, który zachował jedyny przekaz tekstu Vita uel passio Benedicti et Iohannis sociorumque quorum", ubolewała przeszło cztery dekady temu Jadwiga Karwasińska, wydawczyni Żywotu w serii Pomników Dziejowych Polski ${ }^{1}$. Nieco zaś wcześniej Walerian Meysztowicz chmurnie wieszczył, że „,nous ne saurons jamais quelle fut la bibliothèque d'une congrégation sécularisée en Allemagne, détruite par la Révolution Française, pillée au cours des invasions de la Pologne, où ailleurs, dont notre volume provenait"2. Niniejszy artykuł jest próbą wyjaśnienia zarówno pochodzenia, jak i historii kodeksu opatrzonego sygnaturą theol. lat. oct. 162, obecnie znajdującego się w zbiorach Biblioteki Państwowej w Berlinie. Studia porównawcze nad stylistyką inicjałów oraz iluminacji zdobiących niektóre spośród zawartych w pasjonale utworów skłoniły Andreasa Fingernagla do postawienia hipotezy o pochodzeniu kodeksu

\footnotetext{
* Tekst niniejszy powstał w ramach stażu podoktorskiego NCN FUGA 2013/08/S/HS3/00188. Autopsja kodeksów w lutym 2014 r. Na późnym etapie procesu wydawniczego autor natrafił na nowy opis kodeksu theol. lat. oct. 162 (Beate Braun-Niehr, baza danych Manuscripta Mediaevalia: <http://www.manuscripta-mediaevalia.de/dokumente/html/obj31101702> [dostęp 29.09.2016]). Opis ten niezależnie i w sposób syntetyczny, podaje część ustaleń zawartych w artykule (notatka własnościowa Huysburga, katalog aukcyjny „Bibliotheca Büloviana”, kodeks z Ebrach-Nepomuk). Wciąż widoczny jest poprzedni opis katalogowy, który był znany autorowi w lutym 2014 r., podczas pracy nad historią kodeksu: $<$ http://www.manuscripta-media evalia.de/dokumente/html/obj90432270,T> [dostęp 29.09. 2016].

1 J. Karwasińska, Wstęp, w: MPH s.n., t. 4, cz. 3, Warszawa 1973, s. 13.

2 W. Meysztowicz, La vocation monastique d'Otton III, „Antemurale”, 4, 1958, s. 54.
} 
z klasztoru w Huysburgu ${ }^{3}$. Uwagi tego badacza stały się dla mnie impulsem do przebadania kodeksu na nowo, w ramach przygotowań do nowej edycji dzieł wszystkich Brunona z Kwerfurtu. Prezentowane tu uwagi stanowią weryfikację domysłu Fingernagla na innym gruncie, mniej subiektywnym, niż stylistyka iluminacji. Już po złożeniu tego artykułu do druku okazało się, że krok w tym kierunku zrobił wcześniej Hartmut Hoffmann ${ }^{4}$. Dalsze spostrzeżenia przynoszą szereg nowych ustaleń na temat historii kodeksu do momentu jego odnalezienia w 2 poł. XIX w., zaś w ostatniej części pracy zastanawiam się nad hipotetycznymi drogami wędrówki tekstu „Żywotu Pięciu Braci” (dalej VQF), będącego podstawą omawianej kopii.

Problemem powstania i historii kodeksu zawierającego jedyny zachowany odpis tzw. Żywota Pięciu Braci jako pierwszy zajął się jego odkrywca, Reinhard Kade (1859-1936)5. Ze względu na okoliczności odnalezienia kodeksu: w rodzinnych zbiorach, bez poświadczonej proweniencji, nie sposób jednak było wyjść poza informacje przekazane przez Kadego. Przełom w tej kwestii, podobnie jak w wielu innych przypadkach, przynieść może systematyczny postęp w badaniach, i to nie nad konkretnymi kodeksami a nad dziejami skryptoriów oraz powiązań między nimi, dających się na podstawie zachowanych rękopisów zauważyć. Dopomóc może również, jak w tym przypadku, łut szczęścia i uparte podążanie tropami, które z początku wydają się mało obiecujące.

\section{Podstawowe informacje na temat kodeksu theol. lat. oct. 162}

Podstawowe informacje o kodeksie wynotowują katalogi biblioteczne i opracowania szczegółowe, więc nie ma potrzeby powtarzać tutaj ich wszystkich ${ }^{6}$. Niewielki klocek ${ }^{7}$, oprawiony w XV w., składa się z trzech części, z których pierwszą i najstarszą jest pochodzący z 2 poł. XII w. albo z przełomu XII i XIII w. łaciński pasjonał, zawierający czternaście utworów hagiograficznych. Terminus ante quem stanowić ma dla niego zapis cyframi arabskimi daty rocznej 1204, wkomponowany w iluminowany inicjał $Q$ na f22r. Na drugą część, pochodzącą z XV w., składa się jeden utwór hagiograficzny oraz

\footnotetext{
3 A. Fingernagel, Die illuminierten lateinischen Handschriften süd-, west- und nordeuropäischer Provenienz der Staatsbibliothek zu Berlin Preussischer Kulturbesitz, t. 4: 12. Jahrhundert, cz. 1. Text. Mit Nachträgen zu Bd. 1, Staatsbibliothek Preussischer Kulturbesitz. Kataloge der Handschriftenabteilung 3, Illuminierte Handschriften; 2/1-2), Wiesbaden 1991, s. 21-22; podobizny inicjałów ( $\mathrm{nr}$ 46-50) w: t. 2: Abbildungen, s. 35]. Ostatnie opracowania już to odnotowują; np. Europas Mitte im 1000. Austellungskatalog, red. A. Wieczorek, H.-M. Hinz, Stuttgart 2000, s. 416 (ze znakiem zapytania); W. Milde, Huysburg. Bibliotheksgeschichte, w: Die Mönchsklöster der Benediktiner in Mecklenburg-Vorpommern, Sachsen-Anhalt, Thüringen und Sachsen, red. Ch. Römer, M. Lücke, (Germania Benedictina, t. 9, cz. 1-2), Sankt Ottilien 2012, s. 676 (bez znaku zapytania; przyp. 326 z powołaniem na Fingernagla).

${ }^{4}$ H. Hoffmann: Handschriftenfunde, (MGH Studien und Texte, t. 18), Hannover 1997, s. 28

${ }^{5}$ Po lipskich i berlińskich studiach filologiczno-historycznych pod okiem m.in. Ernsta Curtiusa, Theodora Mommsena, Wilhelma Wattenbacha oraz obiecującym starcie mediewistycznym związanym z odkryciem kodeksu theol. lat. oct. 162 i poświęceniem zagadnieniom z nim związanym kilku rozprawek, Kade został jednak historykiem muzyki oraz nauczycielem (Oberstudienrat) w Dreźnie. Syn znanego muzykologa Ottona Kadego (1819-1900), pomagał ojcu w katalogowaniu muzykaliów szweryńskich. Daty urodzenia O. Kadego (1825) i R. Kadego (1860) podane przez Waleriana Meysztowicza, La vocation monastique, s. 54, są błędne. Por. autoprezentację R. Kade, De Brunonis Querfurtensis vita quinque fratrum Poloniae nuper reperta, Lipsiae 1883, s. 32 oraz H. Erdmann, Kade, Otto, w: Neue Deutsche Biographie, t. 10, Berlin 1974, s. 720 .

${ }^{6}$ Zob. R. Kade, Beschreibung eines Legendars, „Neues Archiv”, 8, 1883, s. 365-367; tenże, De Brunonis, s. 4.; tenże, [Wstęp], w: MGH SS, t. 15, cz. 2, Hannoverae 1888, s. 709nn; J. Karwasińska, Wstęp, w: MPH s.n., t. 4, cz. 3, s. 13nn; A. Fingernagel, Die illuminierten, s. 21nn. Najnowszy katalog rękopisów berlińskich o ciągu sygnatur theol. lat. oct. obejmuje numery od 66 do 125; zob. B. Braun-Niehr, Die theologischen lateinischen Handschriften in octavo der Staatsbibliothek zu Berlin Preussischer Kulturbesitz, t. 1: Ms. theol. lat. oct. 66-125, (Staatsbibliothek zu Berlin Preußischer Kulturbesitz. Kataloge der Handschriftenabteilung, Erste Reihe t. 3, cz. 1), Wiesbaden 2007.

${ }^{7}$ Kodeks jako taki ok. $19 \times 14 \times 6 \mathrm{~cm}$; karty $18 \times 12 \mathrm{~cm}$, lustro tekstu w interesującym nas pasjonale $14 \times 10 \mathrm{~cm}$.
} 
pieśń Noli me tangere wraz z notacją. Trzecia, XIV-wieczna, to traktat Speculum Marię; na odwrocie ostatniej karty zapisano modlitwę o usunięcie zmazy z oczu'

Reinhard Kade, opierając się raczej na ustnej tradycji rodzinnej (ut opinor), niż na dokumentach, przedstawił historię kodeksu następująco: Na mniej więcej czterdzieści lat przed odkryciem, a więc w latach czterdziestych lub trzydziestych XIX w., rękopis nabyć miał w Nordhausen dziad stryjeczny (patruus magnus) Kadego, Anton Krüger, znany chalcographus drezdeński. Jadwiga Karwasińska objaśnia to słowo błędnie jako „drukarz”, tymczasem Ferdinand Anton Krüger (ur. 1795 w Loschwitz, obecnie dzielnicy Drezna, zm. 1857 tamże) był znanym rytownikiem oraz profesorem na drezdeńskiej Akademii Sztuk Pięknych ${ }^{10}$. W każdym razie sprzedawcą miał być, dość sztampowo, pewien bliżej nieokreślony „vir doctissimus”, który „ibi [w Nordhausen - M.S.] prefectus thesauri rerum vetustate ac raritate notabilium". Opis, czy raczej błędna interpretacja, Meysztowicza, który określa sprzedającego jako rzekomego dyrektora muzeum drezdeńskiego o nazwisku Northusen wynika z innego rozumienia niejasnej łaciny wstępu w MGH i omyłkowego — jak sądzę — uznania zlatynizowanej nazwy miejscowości Nordhausen za nazwisko ${ }^{11}$. Podkreślić warto, że w napisanych kilka lat wcześniej rozprawach, Kade już to nie określał miejsca nabycia kodeksu' ${ }^{12}$, już to przyznawał, że nie wie, gdzie to nastąpiło ${ }^{13}$. W każdym razie rękopis wszedł następnie do zbiorów biblioteki rodziny Kade w Schwerinie, gdzie przeleżał zapomniany w jakiejś skrzyni niemal ćwierćwiecze (ut fere quinque lustra), co z grubsza zgadza się z liczbą lat jakie upłynęły między śmiercią Krügera (1857) a pierwszą publikacją Kadego (1883).

Jako dar odkrywcy wszedł kodeks do zbiorów berlińskiej Königliche Bibliothek w 1899 roku pod nr. akcesji 1899, $76^{14}$. Potem, choć od trzech lat spoczywał już Berlinie, mianowany został szweryńskim (suerinensis), jak nazwali go Oswald Holder-Egger i Bruno Krusch, wskazując na siedzibę rodowej biblioteki ${ }^{15}$. Później zaś, w co najmniej jednej rozprawie posłużono się do jego opisania nazwą utworzoną od imienia i nazwiska ojca odkrywcy, Ottona Kadego (codex Otto Kade) ${ }^{16}$. W czasie drugiej wojny światowej, której zmarły w 1936 r. Reinhard Kade nie dożył, wraz z innymi zbiorami Staatsbibliothek, kodeks znalazł się w Marburgu an der Lahn i dopiero po zjednoczeniu Niemiec powrócił do Berlina.

\section{Nota własnościowa theol. lat. oct. 162}

Kodeks nie jest opatrzony żadnymi znakami własnościowymi, sygnaturami ${ }^{17}$, czy pieczęciami pochodzącymi sprzed włączenia go w obieg w XIX w., aczkolwiek możliwe, że takowe zawierał. Opisy kodeksu nie zwracają mianowicie uwagi na ubytki, takie jak piętka, będąca śladem po usuniętej karcie

\footnotetext{
8 To ostatnie wraz z edycją, zob. R. Kade, Ein Augensegen, „Neues Archiv”, 10, 1885, s. 186-191.

9 J. Karwasińska, Wstęp, w: MPH s.n., t. 4, cz. 3, s. 13.

${ }_{10}$ Pochodził zresztą z rodziny o tradycjach artystycznych, gdyż jego ojciec i brat byli medalierami mennicy drezdeńskiej. Zob. hasła Krüger Anton, w: Pierer's Universal-Lexikon, t. 9, Altenburg 1860, s. 852-853 oraz Krüger Anton, w: Allgemeine Deutsche Biographie, t. 17, Leipzig 1883, s. 223.

${ }^{11}$ Księgi adresowe Drezna za 1. 1831-1850 (dostępne na: <http://adressbuecher.sachsendigital.de>) nie wymieniają takiej osoby, zaś ponad trzystustronnicowy indeks do czterech tomów Deutscher Familiennamenatlas nie zna nazwiska Northusen (zob. <http://www.namenforschung.net/dfa/downloads/> [dostęp 28.03.2014]).

12 R. Kade, Beschreibung, s. 365.

13 Tenże, De Brunonis, s. 4.

${ }_{14}$ Wyklejka na lustrze oprawy głosi: Codex XIII. saeculi Vitas et passiones continens ex bibliotheca R. Kade, 1887.

15 W opisie tradycji rękopiśmiennej Vita Columbani, wyd. B. Krusch, w: MGH SSrM, t. 4., Hannoverae et Lipsiae 1902, s. 43. Omawiany tu rękopis zbadał Holder-Egger. Późniejsze wydanie Vita Columbani (MGH SSrG, t. 37, wyd. B. Krusch, Hannoverae et Lipsiae 1905, s. XI i 102) oraz edycja Passio Kiliani (MGH SSrM, t. 5, wyd. B. Krusch, Hannoverae et Lipsiae 1910, s. 718) wskazują już na Schwerin oraz na Berlin.

16 W. Meysztowicz, La vocation monastique, s. 53-55.

17 W momencie odkrycia kodeksu (R. Kade, Beschreibung, s. 365) na odwrocie okładki przyklejona była karteczka z numerem (sygnatury?) 44, ale dziś nie ma po niej śladu.
} 
poprzedzającej dzisiejsze f1, oraz kwadratowe wycięcia ok. $35 \times 35 \mathrm{~mm}$, obecne w dolnej zewnętrznej części lustra zarówno f65, jak i na kończącej pasjonał, czyli najdawniejszą część klocka, karcie 110 (tekst jedynie na f110r, verso pusta), które mogą być śladami po znakach własnościowych. Powstałe na drodze autopsji publikacje dotyczące kodeksu' ${ }^{18}$, nie wspominają również o trzeciej, najważniejszej poszlace.

Na f110v, poniżej górnej krawędzi karty, znajduje się wyblakły tekst w jednym wierszu, w dużej mierze nieczytelny, być może niegdyś razurowany. Widoczne do dziś ciągi liter układają się w napis dający się rozwiązać jako $<$ B.V./s/b $M>$ arie in Huusb $<$ urch/a est $>$ lib $<$ er iste >. Już po złożeniu niniejszego artykułu do druku natrafiłem na krótką wzmiankę Hartmuta Hoffmanna, który zaproponował odczyt niemal identyczny: „Sc̄e (oder bēe) Marie in Huusburch est liber iste" ${ }^{19}$.

Rekonstrukcja taka ma swoje odpowiedniki w brzmieniu dalej opisanych not własnościowych innych kodeksów huysburskich. To, że kodeks był wtórnie zmniejszany, o czym dalej, pozwala domyślać się, że napis mógł być nawet dłuższy. Odczyt ten jest zaledwie jedną z możliwości, ale również pozostałe przedstawione $\mathrm{w}$ tym artykule cechy kodeksu — i jego historia — jednoznacznie wskazują na Huysburg. Litery są tak zatarte, że nie sposób określić wieku zapiski, ale wydaje się, że nosi ona cechy późnej minuskuły karolińskiej, więc nie może być dużo późniejsza niż passionale. W każdym razie nota własnościowa nie mówi nam o pochodzeniu kodeksu, lecz o pierwszym dającym się zidentyfikować miejscu przechowywania pasjonału. W związku z tym, że opatrzono nią nie kodeks jako całość, lecz jedynie pasjonał, można zakładać, że we wcześniejszym okresie - niekoniecznie w Huysburgu - ten ostatni funkcjonował jako osobna jednostka kodykologiczna (albo, że kończył on jakiś inny kodeks). Po drugie, umiejscowienie zapisu wskazuje na to, że pasjonał znalazł się w posiadaniu klasztornej biblioteki przed złożeniem składek w nową całość w postaci obecnego klocka. Na rzecz tego świadczą również cechy okładziny, o których za chwilę.

\section{Nota własnościowa na tle pozostałych berlińskich kodeksów z Huysburga}

Za jednym wyjątkiem ${ }^{20}$ wszystkie pozostałe obejrzane przeze mnie berlińskie rękopisy podejrzewane o proweniencję huysburską ${ }^{21}$ zawierają noty własnościowe ${ }^{22}$.

\footnotetext{
${ }^{18}$ Czyli Reinhard Kade, Oswald Holder-Egger, Andreas Fingernagel oraz Jadwiga Karwasińska. Sprawa autopsji kodeksu przez Jadwigę Karwasińską jest niejasna. Z jeden strony wydawczyni VQF opisuje swą edycję jako sporządzoną na podstawie mikrofilmu rękopisu. Z drugiej strony zaś dziękuje Bibliotece Narodowej za wypożyczenie kodeksu z Marburga celem przeprowadzenia przez Krystynę Białoskórską studium inicjałów; zob. J. Karwasińska, Wstęp, w: MPH s.n., t. 4, cz. 3, s. 14, p. 21.

19 Zob. H. Hoffmann: Handschriftenfunde, (MGH Studien und Texte, t. 18), Hannover 1997, s. 28, p. 30, gdzie również podziękowania dla Hansa Jakoba Schuffelsa (Getynga) za informację o zapisce. Znane mi opracowania wskazujące na Huysburg jako miejsce pochodzenia kodeksu powołują się jedynie na studium Fingernagla, bez wzmianki o odkryciu Hoffmanna; zob. wydany w 2012 r. W. Milde, Huysburg. Bibliotheksgeschichte, s. 676.

${ }^{20}$ Wyjątkiem jest rkps. o sygn. lat. fol. 926, posiadający najbardziej zdobną ze wszystkich oprawę tłoczoną oraz — jako jedyny — znak wodny na wyklejce: głowa byka przebita strzałą, powyżej kwiat, poniżej zaś trójkąt z rozłożonym cyrklem i dwiema kropkami pomiędzy.

${ }^{21}$ S. Krämer, Mittelalterliche Bibliothekskataloge Deutschlands und der Schweiz. Ergänzungsband I: Handschriftenerbe des deutschen Mittelalters, t. 1: Aachen-Kochel, München 1989, s. 369-370; A. Fingernagel, Die illuminierten lateinischen Handschriften, s. 21-22; W. Milde, Huysburg. Bibliotheksgeschichte, s. 676.

${ }^{22}$ Autopsja w lutym 2014 r. Są to kodeksy: datowany, podobnie jak nasz, na 2 poł. XII w. (por. A. Fingernagel, Die illuminierten lateinischen Handschriften, s. 21, poz. 20) i oprawiony w bardzo podobną oprawę z XV w., theol. lat. fol. 499, na karcie ochronnej późnośredniowieczna nota: Omelie Augustini episcopi Liber iste est sanctę dei Genitricis Marie in Huysburch. oraz kilkukrotnie hathilt s. Marię (np. f48r, f103r, f133r); kodeks papierowy z XV w., sygnatura lat. oct. 364, na 1fr: liber beate marie virginis in $\langle h\rangle$ uisborx oraz minią: liber monasterii beate marie in huysborch; podobny do niego kodeks papierowy z XV w., theol. lat oct. 117, na podklejce oprawy wytarte: liber monast<erii> ... Huysborcha, zaś na czystej karcie przed f1r na dole ręką XVI-XVIII w.: Liber B.M.V. in Huysburg; papierowy kodeks theol. lat. oct. 118 z w. XV, na podklejce oprawy ręką XV w.: liber monasterii beate marie virginis in Huysborch oraz, podobnie jak w lat. oct. 364, minią: Liber beate marie virginis in huysborx; pergaminowy kodeks z XV w. theol. lat. fol. 501 na f1r: liber beatissime dei geni-
} 
Nota własnościowa $\mathrm{z}$ omawianego pasjonału nie różni się specjalnie formułą zapisu od pozostałych. Wszystkie one są późniejsze od noty w pasjonale, ale też oznaczone nimi kodeksy, za wyjątkiem theol. lat fol. 499, pochodzą z późnego średniowiecza. Podkreślić warto, że późnośredniowieczną notę własnościową zawierał zapewne również interesujący nas kodeks 162, ale te zwykle - jak widać z zaprezentowanego zestawienia — nanoszone były na kartę ochronną, względnie na podklejkę oprawy. Zarówno jedno, jak i drugie zostało z naszego kodeksu usunięte, o czym więcej dalej.

\section{Podobieństwa do rękopisu theol. lat. fol. 499}

Najdalej idące podobieństwa do theol. lat. oct. 162 pod względem techniki i stylu wykonania oprawy odnotowujemy w przypadku kodeksu theol. lat. fol. 499. Na podobieństwo oprawy i zapinki zwrócił uwagę już Fingernagel ${ }^{23}$, ale na tyle lakonicznie, że sprawę warto przedstawić bardziej szczegółowo. I tak: choć kodeks Kadego jest zdecydowanie bardziej zniszczony, to jednak da się stwierdzić, że nacięcia w lustrze okładziny są bardzo podobne, tj. podwójne linie ryte z kółkami w miejscach przecięcia. Podobieństwo lustra widoczne jest bardziej na tylnej okładzinie, mniej zniszczonej niż przednia. Na frontowym lustrze oprawy widoczne są ślady po ćwiekach narożnych oraz centralnym, będących elementami zdobnego motywu rytego okładziny. Identyczne są klamry spinające, tyle, że w przypadku górującego rozmiarami kodeksu theol. lat. fol. 499 są one odpowiednio większe. Pergaminowa wyklejka z tekstem łacińskim pokrywa wewnętrzne lustro okładziny theol. lat. fol. 499. Analogiczna, dziś zaginiona, pokrywała także okładziny kodeksu Kadego, ale obecnie pozostał po niej jedynie odciśnięty fragment Ewangelii według św. Mateusza ${ }^{24}$. Warto dodać, że kodeks zawiera również, identyczne jak nasz, ubytki w postaci wyciętych kwadratów (np. f36).

\section{Podobieństwa opraw berlińskich kodeksów z Huysburga}

Początki dziesięciu zawartych w pasjonale theol. lat. oct. 162 tekstów oznaczone są dziesięcioma skórzanymi rączkami ${ }^{25}$, przy czym dodatkowo jedna znajduje się na karcie początkowej Descendis domine super equos tuos ${ }^{26}$. Rączki te więc zostały umieszczone w kodeksie dopiero po złożeniu go w klocek z pozostałymi składkami w XV w., a więc na pewno w Huysburgu. Podobne i w jednakim kolorze znajdziemy je w XV-wiecznych huysburskich rękopisach papierowych lat. oct. 364 i theol. lat. oct. 117, a także w pergaminowym theol. lat. fol. 501.

$\mathrm{Na}$ wspólną proweniencję wskazuje również podobieństwo stylistyczne opraw. Nie chodzi tylko o to, że zarówno większe kodeksy, w formacie quarto i folio, oprawne są, podobnie jak nasze octavo, w jasną skórę. Analogiczne są rozwiązania szczegółowe. Dużym podobieństwem do theol. lat. oct. $162 \mathrm{i}$ theol. lat. fol. 499 cechuje się również kodeks lat. oct. 364, z oprawą również rytą w linie romboidalne, lecz potrójne, przy czym jest ona bardziej zdobna, bo zawiera floralne motywy na obrzeżach. Kodeks ten również cechuje się identyczną techniką wpięcia klamry w oprawę. Pewne podobieństwa stylistyczne oprawy do powyższych daje się też zauważyć w theol. lat. oct. 117 oraz theol. lat. oct. 118.

tricis marie [na razurze:] Husburgh, zaś na f2r: hunc librum scripsit A.F. Henricus Beyer \| Monasterii B.M.V. in Huysburg || Professus Anno Domini 1474; podobny do niego z XV w. pergaminowy theol. lat. fol. 661 na nienumerowanej karcie ochronnej ręką XV w.: Liber sancte marie virginis in Huysburch; niedbale złożony i bardzo zniszczony klocek theol. lat. quart. 238 ręką XV w. na f1r opatrzony jest natomiast notą cystersów z Eberbach: Liber Virginis gloriose in Ebirbach hic est Marie ad Virg 〈inem> Abbatię Ebirbacen〈sis〉.

${ }_{23}$ A. Fingernagel, Die illuminierten lateinischen Handschriften, s. 22, gdzie „,der Einband u. die Schließen sehr ähnlich bei Ms. theol. lat. fol. 499, das sicher aus Huysburg stammt”.

${ }^{24}$ Mt 10:16, co zidentyfikował już R. Kade, Beschreibung, s. 367.

${ }^{25}$ Pełnią one funkcję permanentnych zakładek. W przypadku VQF jest to początek samego żywota, a nie początek poprzedzającego prologu.

${ }^{26}$ Por. Ha 3,1. 


\section{Opactwo w Huysburgu}

Wskazane cechy wspólne opraw wskazują na to, że w swej obecnej postaci kodeks theol. lat. oct. 162 był własnością klasztoru w Huysburgu. Nota własnościowa z kolei nie pozwala mieć wątpliwości, że w okresie poprzedzającym złożenie kodeksu jako całości również stojący na czele klocka pasjonał należał do huysburskich zbiorów.

Początki benedyktyńskiego opactwa św. Marii w Huysburgu ${ }^{27}$ (diecezja Halberstadt) sięgają Bożego Narodzenia 1080 roku, kiedy to za pontyfikatu biskupa halberstadzkiego Burcharda II (+1088) powołany został klasztor podwójny, tj. gromadzący zarówno mniszki jak i mnichów ${ }^{28}$. Impulsem do założenia wspólnoty były nalegania dwóch pustelnic, żyjących w celkach przyległych do budynku kościoła, które wbrew miejscowemu kanonikowi domagały się przysłania mnichów, będących w stanie pokierować ich życiem duchowym ${ }^{29}$. Po perypetiach związanych z trwającym kilkadziesiąt lat procesem usuwania z niego mniszek, na początku XII w. klasztor przystąpił do ruchu reformy życia monastycznego, na czele którego stało pobliskie opactwo w Ilsenburgu ${ }^{30}$. Huysburg objęła potem reforma bursfeldzka, o czym dalej. Po przeszło siedmiu stuleciach istnienia klasztor został zniesiony przez króla pruskiego Fryderyka Wilhelma III w 1804 roku $^{31}$. W 1972 r. w mury klasztorne wrócili mnisi, którzy założyli tam jedyny klasztor benedyktyński w historii NRD ${ }^{32}$. Obecnie podlega on opactwu św. Macieja w Trewirze.

Leżące na północnym przedpolu Harzu pasmo wzniesień Huy, od którego nazwę bierze Huysburg, zasiedlone było $\mathrm{w}$ interesującym nas okresie XI-XII w., podobnie zresztą, jak rodzinny Kwerfurt Brunona ${ }^{33}$, ludnością w dużej mierze słowiańską, ale wraz z germańskimi sąsiadami poddaną opiece duszpasterskiej, czyli tzw. misji wewnętrznej. Diecezja Halberstadt, na terenie której leżał nasz klasztor, miała również powinności misyjne w stosunku do zwartego i w znakomitej większości pogańskiego osadnictwa słowiańskiego na wschód od Soławy i Łaby, ale w XI i XII w. spełniane przeważnie poprzez organizowanie wypraw wojennych. Wspomniany już Burchard II na dwadzieścia lat przed założeniem Huysburga powiódł jedną z nich przeciw Lucicom, co zakończyło się spaleniem świątyni w Radogoszczy, z której to biskup halbersztadzki wrócił na świętym koniu Swarożyca ${ }^{34}$.

\section{Biblioteka i skryptorium (?) Huysburga}

Skryptorium Huysburga nie doczekało się osobnego studium. Co więcej, nie udało się, jak dotąd, wypracować jednoznacznego stanowiska w sprawie istnienia w tym klasztorze skryptorium. Aliza Cohen-Mushlin, autorka monografii skryptorium w pobliskim Hamersleben, uważa, że zwłaszcza

\footnotetext{
27 Najnowszym i najpełniejszym opracowaniem jest praca zbiorowa: Huysburg. Bibliotheksgeschichte, w: Die Mönchsklöster der Benediktiner in Mecklenburg-Vorpommern, Sachsen-Anhalt, Thüringen und Sachsen, red. Ch. Römer, M. Lücke, (Germania Benedictina, t. 9, cz. 1-2), Sankt Ottilien 2012, s. 627-697, gdzie również obszerna bibliografia. Ze starszych prac zob. Th. Eckart, Geschichte des Klosters Huysburg bei Halbertstadt, (Geschichte der Burgen und Klöster des Harzes, t. 6), wyd. 2, Leipzig 1905. Krótkie ujęcia słownikowe zob. Répertoire topo-bibliographique des abbayes et prieurés, t. 1: A-L, oprac. L.-H. Cottineau OSB, Mâcon 1936, s. 1439; K. Blaschke, Huysburg, w: Lexikon des Mittelalters, t. 5, kol. 240.

${ }^{28}$ K. Bogumil, Das Bistum Halberstadt im 12. Jahrhundert. Studien zur Reichs- und Reformpolitik des Bischofs Reinhard und zum Wirken der Augustiner-Chorherren, (Mitteldeutsche Forschungen, t. 69) Köln 1972, s. 67-69.

${ }^{29}$ Utwór opisujący m.in. pierwsze lata istnienia klasztoru został wydany jako Der, Chronicon Hujesburgense', wyd. O. Menzel, „Studien und Mitteilungen zur Geschichte des Benediktinerordens und seiner Zweige”, 52, 1934, s. $130-146$.

${ }^{30}$ Ch. Römer, Huysburg. Geschichte, w: Die Mönchsklöster der Benediktiner, s. 629nn. Krótko zob. D. Pötschke, Kloster Ilsenburg - Geschichte, Architektur, Bibliothek, (Harz-Forschungen, t. 19), Berlin 2004, s. 43nn.

31 A. Dylong, Huysburg. Geschichte, w: Die Mönchsklöster der Benediktiner, s. 658-659.

${ }^{32}$ P. Henke, A. Pfeil, Huysburg. Geschichte, w: Die Mönchsklöster der Benediktiner, s. 660-661.

${ }^{33}$ Przykłady wraz z dalszą literaturą podaje M. Cottin, Die Lebenswelt Bruns von Querfurt im Spiegel zeitgenössischer Urkunden, w: Der Heilige Brun von Querfurt. Eine Reise ins Mittelalter. Begleitband zur Sonderaustellung, red. J. Rudolph, M. Kühnel, Querfurt 2009, s. 67-69.

${ }^{34}$ Th. Schieffer, Burchard II. (Bucco), w: Lexikon des Mittelalters, t. 2, kol. 943-944.
} 
w w. XII teksty kopiowano w Huysburgu na relatywnie dużą skalę i domyśla się, że zajęciem tym trudniły się również mniszki, a na podstawie cech stylistycznych sądzi, że utrzymywały one kontakty $\mathrm{z}$ innymi skryptoriami saskimi w diecezjach halbersztadzkiej i hildesheimskiej ${ }^{35}$. Z drugiej strony najnowsze opracowania podkreślają, że nie mamy pewności, czy pochodzące z końca XII w. rękopisy zostały wykonane na miejscu, czy zostały sprowadzone ${ }^{36}$.

Kodeksy o pewnej oraz o przypuszczalnej atrybucji huysburskiej są obecnie rozproszone. Obok londyńskiej British Library (12 rkps.) największą ich liczbę przechowuje Staatsbibliothek w Berlinie (9 lub 10 rkps. w zależności od trafności atrybucji) ${ }^{37}$. W Huysburgu z całą pewnością istniała więc dość duża biblioteka. Pierwszy jej rozkwit nastąpił już w XII w. Opactwo zawdzięczało to hojnej trosce Reinharda, biskupa Halberstadt ${ }^{38}$. To wkrótce po jego śmierci w 1123 r. skomponowany został utwór o założeniu klasztoru; jedyny tak wczesny tekst literacki związany z Huysburgiem ${ }^{39}$. Drugim momentem skokowego rozwoju jest II połowa XV w., gdy w klasztorze wprowadzano reformy związane z przystąpieniem do kongregacji bursfeldzkiej ${ }^{40}$. Przy tej okazji powiększono zarówno sam budynek biblioteki, jak i przechowywane w nim zbiory. W 1525 r., w czasie tzw. wojny chłopskiej, opactwo zostało splądrowane. Spaleniu oraz rabunkowi uległo wówczas tak wiele rękopisów i druków, że Carl van Ess, ostatni przeor przed likwidacją, w swojej historii klasztoru twierdził, że Huysburg stracił wszystkie swoje książki ${ }^{41}$. To oczywiście przesada. W chwili kasaty zbiory biblioteki liczyły bowiem około 4000 druków i kilkaset rękopisów, a oficjalny dostęp do nich umożliwiono w pierwszej kolejności Uniwersytetowi w Halle, dokąd wkrótce powędrowały skrzynie z książkami ${ }^{42}$. Zanim to jednak nastąpiło, część zbiorów została zakupiona na miejscu. Wśród nabywców, obok instytucji, jak British Museum, znalazły się osoby prywatne. Spośród nich najwięcej zakupów dokonał teolog, autor przekładu Pisma Świętego na niemiecki, a zarazem kuzyn i współpracownik ostatniego przeora, Leander van Ess (zm. 1847) ${ }^{43}$. Rzucony z powrotem na łono świata benedyktyn, mimo że niezamożny, zdobył na fali sekularyzacji, często na nominalną cenę, olbrzymią kolekcję rękopisów ${ }^{44}$. Nasz rękopis nie przeszedł raczej przez jego ręce, bowiem katalog wystawionych w Darmstadt w 1823 roku na aukcję zbiorów Leandra nie zawiera naszego kodeksu ${ }^{45}$.

\footnotetext{
35 A. Cohen-Mushlin, Scriptoria in Medieval Saxony. St. Pancras in Hamersleben, Wiesbaden 2004, s. 19, 171-176, 181, gdzie też wskazanie na podobieństwo stylistyczne iluminacji theol. lat. oct. 162 do innych kodeksów huysburskich, które zachowały się w innych bibliotekach.

${ }^{36}$ W. Milde, Huysburg. Bibliotheksgeschichte, s. 674 oraz A. Cohen-Mushlin, Scriptoria, s. $171 \mathrm{nn}$.

${ }^{37}$ Rękopisy huysburskie znajdują się też w Cambridge, Downside Abbey, Dreźnie, Durham, Edynburgu, Halle, Lejdzie, Londynie, Nowym Jorku, Oxfordzie, Princeton N.J. oraz Wolfenbüttel. Zob. S. Krämer, Mittelalterliche Bibliothekskataloge, s. 369-370.

38 W. Milde, Huysburg. Bibliotheksgeschichte, s. 674.

39 Chronicon Hujesburgense; zob. przyp. 25.

${ }^{40}$ Ch. Römer, Huysburg. Geschichte, s. $639 \mathrm{nn}$. Na temat reformy zob. W. Ziegler, Die Bursfelder Kongregation, w: Die Reformverbände und Kongregationen der Benediktiner im deutschen Sprachraum, (Germania Benedictina, t. 1), U. Faust, F. Quarthal, St. Ottilien 1999, s. 315-407.

${ }^{41}$ C. van Ess, Kurze Geschichte der ehemaligen Benedictinerabtei Huysburg: nebst einem Gemälde derselben und ihrer Umgebungen, Halberstadt 1810, s. 25.

${ }^{42}$ W. Milde, Huysburg. Bibliotheksgeschichte, s. 674-675.

${ }_{43}$ Tamże, s. 675-676.

${ }^{44} \mathrm{~W}$ całości zbiory te nabył Thomas Philips, jeden z najaktywniejszych kolekcjonerów w tym okresie. Zob. M. McCormick Gatch, The Book Collections and the Library of Leander van Ess, w: , so precious a foundation' the Library of Leander Van Ess at the Burke Library of Union Theological Seminary in the City of New York, red. tenże, New York 1996, s. 47-84.

${ }^{45}$ Sammlung und Verzeichniss handscriftlicher [sic] Bücher aus dem VIII. IX. X. XI. XII. XIII. XIV, etc. Jahrhundert, bestehend aus 171 Bänden auf Pergament, 19 theils auf Pergament theils auf Papier, und 190 auf Papier. Nebst einer Sammlung von alten Holzschnitten und kleinen Gemälden mit Vergoldung, die leider! aus alten Pergament-Handschriften ausgeschnitten sind, welche besitzt Leander van Ess, Theol. Doctor, vorhin Professor und Pfarrer in Marburg, Darmstadt 1823.
} 


\section{Foliacja, Schäffer i Bibliotheca Büloviana}

Ważnym tropem dla ustalenia proweniencji rękopisu sprzed odnalezienia go przez Reinharda Kadego okazało się podobieństwo duktu pisma osoby nadającej foliację w kilku berlińskich kodeksach wiązanych z Hysburgiem. Zdaniem Jadwigi Karwasińskiej w kodeksie theol. lat. oct. 162 została ona nadana w XIX w. kilkoma rękami ${ }^{46}$. To ostatnie trzeba doprecyzować — w istocie bowiem wyraźnie rozróżnić da się dwie ręce, a wręcz dwie foliacje (obydwie cyframi arabskimi). Jako pierwsza sporządzona została, pismem o dużym module, foliacja czarnym atramentem. Pojawia się ona nieregularnie, częściej w okolicach początków kolejnych tekstów. W późniejszym okresie uzupełniano ją mniejszymi cyframi atramentem jaśniejszym. Zdarza się, że dana karta (np. f50r) opatrzona jest obydwiema foliacjami.

W kodeksie berlińskim theol. lat. fol. 499 z Huysburga pierwsza karta pozbawiona jest foliacji, która następuje dalej cyframi rzymskimi z XV w. Cyframi arabskimi zaś zaznaczona została w XIX w. foliacja odmienna, uwzględniająca kartę ochronną, na wybranych, ponownie dość losowo, stronach. Pismo foliacji cyframi arabskimi jest identyczne, jak w theol. lat. oct. 162. W theol. lat. fol. 499 tym samym charakterem pisma oraz czarnym atramentem sporządzono na karcie ochronnej odręczną notatkę 149.131 in. 17. Marz 1835 || Beyern. G.H. Schr. Zapiska świadczy o tym, że foliacja w tym kodeksie została nadana przez Georga Heinricha Schäffera w Beyernaumburgu, który katalogował tam przeznaczone na sprzedaż zbiory Friedricha von Bülow ${ }^{47}$. Identyczność duktu foliacji każe domyślać się, że dotyczy to również theol. lat. oct .162 .

Friedrich Gottlieb Julius von Bülow (1760-1831), asesor Wyższego Sądu Dworskiego Królestwa Saksonii (Oberhofgerichtsassessor), namiętnie skupował zbiory sekularyzowanych na początku XIX wieku instytucji kościelnych ${ }^{48}$. Na podstawie prezentowanego tu materiału można wysunąć hipotezę, że nabył on również rękopisy zniesionego w 1804 r. klasztoru w Huysburgu ${ }^{49}$. Przeznaczone do sprzedaży po śmierci von Bülowa zbiory katalogował dr Georg Heinrich Schäffer, ur. 1803 w Strasburgu, absolwent tamtejszego Uniwersytetu Królewskiego, który po odbyciu czterech lat studiów na uniwersytecie w Halle od 1832 r. był kuratorem tych zbiorów na zamku w Beyernaumburgu koło Sangerhausen (Saksonia-Anhalt) ${ }^{50}$. Katalog aukcyjny sporządzać zaczął od razu, co potrwać miało 30 miesięcy. Pracy musiało być bardzo wiele, bowiem na sprzedaż wystawiono 118 kufrów z książ$\mathrm{kami}^{51}$. Na pośpiech przy pracy wskazują okazjonalnie pojawiające się błędy w foliacji kodeksów ${ }^{52}$. Termin aukcji w księgarni Reichardta w Eisleben wyznaczono na 1 i 2 czerwca 1835 r. w godzinach od 9 do 12 oraz od 14 do 17. Lista współpracujących składów książek i antykwariatów, zarówno wielu miejscowościach w całych ówczesnych Niemczech, jak i w wybranych miastach w Europie i Stanach Zjednoczonych, jest obszerna ${ }^{53}$.

\footnotetext{
46 J. Karwasińska, Wstęp, w: MPH s.n, t. 4, cz. 3, s. 13.

47 B. Braun-Niehr, Die theologischen lateinischen Handschriften, s. 266

${ }^{48}$ Dotyczące Friedricha von Bülow archiwalia, być może dokumentujące interesujący nas tu nabytek, przechowuje nieobjęte niestety kwerendą archiwum w Wernigerode (Landeshauptarchiv Sachsen-Anhalt, H 28, Gutsarchiv Beyernaumburg). 49 Wyjaśnić to mogłaby kwerenda w archiwum w Wernigerode pod sygn. H 28, Nr. 1240: Ersteigerung von Büchern und Kupferstichen z $1805 \mathrm{r}$.

${ }^{50}$ Informacje biograficzne o nim zob. Statistisches Handbuch der deutschen Gymnasien, für das Jahr 1836, red. C.E. Brauns, A. Theobald, t. 1, Kassel 1837, s. 557.

${ }^{51}$ G.H. Schäffer, Bibliotheca Büloviana: d. i. systematisches Verzeichniss der zum Nachlasse des verstorbenen Friedr. Gottl. Jul. v. Bülow zu Beyernaumburg bei Sangerhausen gehörigen, eben so zahlreichen als werthvollen Sammlung von Büchern und Handschriften aus allen Fächern der Wissenschaften, t. 1, Sangerhausen 1834, s. III.

${ }^{52} \mathrm{~Np}$. theol. lat. fol. 501, gdzie numeracja poprawiona wtórnie ołówkiem, albo theol. lat. fol. 499, który, jak wskazuje zapiska na karcie ochronnej, był katalogowany na trzy miesiące przed rozpoczęciem sprzedaży.

53 Wymieniono firmy z Amsterdamu, Brukseli, Lejdy, Utrechtu, Londynu, Filadelfii, Pragi, Paryża, Pesztu, Kopenhagi, Mediolanu, Baltimore, Sztokholmu, Wiednia i Zürichu. Na liście jest nawet biuro komisowe Glücksberga i Kaczanowskiego w Warszawie, założone niewiele wcześniej na Krakowskim Przedmieściu (zob. „Gazeta Polska”, nr 132 (18 maja 1830 ), s. 2 oraz „Gazeta Korespondenta Warszawskiego i Zagranicznego” nr 133 (8 czerwca 1830), s. 1127).
} 
W w katalogu aukcyjnym Büloviany sporządzonym przez Schäffera znaleźć można obydwa omawiane rękopisy. Jest to prostsze zadanie w przypadku dzisiejszego theol. lat. fol. $499^{54}$, natomiast interesujący nas theol. lat. oct. 162 odnotowany został w dziale quarto zamiast octavo jako: Passiones aliquot martyrum. - Speculum B. V. M. || Membr. von 166 Bl. mit schönen bunten Init ${ }^{55}$.

Lapidarna charakterystyka zbywcy kodeksu, jaką przedstawił Kade, nie pozwala domyślać się, czy zakupu dokonano bezpośrednio na aukcji, czy może rękopis został odkupiony w późniejszym terminie. W każdym razie lista firm uczestniczących w aukcji nie zawiera żadnego podmiotu w Nordhausen, gdzie wedle odkrywcy kodeksu rękopis miał zostać nabyty. Pamiętać jednak należy, że relacjonował on niejasną tradycję rodzinną i albo on, albo ktoś przed nim mógł pomylić miasta. Wszak, o czym wspomniałem wyżej, w najwcześniejszych swych pracach Kade przyznawał, że nie wie, gdzie jego stryjeczny dziad nabył rękopis. W odległości mniejszej niż sto kilometrów od Nordhausen leżą m.in. wymienione z spisie komisów aukcyjnych Brunszwik, Erfurt, Getynga i Halle ${ }^{56}$. Równie blisko jest też do Eisleben, będącego centrum prowadzonej wyprzedaży ${ }^{57}$.

Kodeks theol. lat. oct. 162 zawierał zapewne na karcie ochronnej, podobnie jak pozostałe zbiory przygotowywane na aukcję Büloviany, odręczną notatkę Schäffera, zawierającą datę i miejsce katalogowania. Nie dowiemy się, czy kartę zawierającą zapiskę usunął Anton Krüger, czy przyjmujący kodeks do rodzinnych zbiorów Otto Kade, ojciec Reinharda. Jeżeli stało się to już w Schwerinie, to musiało to nastąpić na tyle dawno przed odkryciem zawartości pasjonału, że Otto Kade już o tym nie pamiętał. Przyczyn usunięcia karty dopatrywać można się w chęci zatarcia historii kodeksu, być może w obawie przed próbami rewindykacji zbiorów rozproszonych w epoce masowych sekularyzacji.

\section{Skutki błędnego określenia formatu kodeksu dla ustalenia ciągłości jego proweniencji}

Rzeczywiste rozmiary kodeksu theol. lat. oct. 162 (oprawa ok. $19 \times 14 \mathrm{~cm}$; karty ok. $18 \times 12 \mathrm{~cm}$ ) są większe od typowych dla formatu in octavo. Zapewne dlatego Schäffer sporządzając katalog zakwalifikował go do kodeksów w formacie in quarto. Dziurkowanie kart przeważnie jest widoczne, ale na niektórych kartach znajduje się na skraju, a czasami nawet jest już obcięte. Ta cecha rękopisu oraz fakt, że niektóre inicjały są nieco ucięte ${ }^{58}$, świadczy, że pasjonał został dość mocno zmniejszony z pierwotnego in quarto. Zapewne stało się to w trakcie współoprawiania z pozostałymi składkami w XV w. Zmniejszeniu uległy zwłaszcza marginesy zewnętrzne i górne. Nieustalona historia rękopisu w połączeniu z odmiennym określeniem formatu kodeksu przez Schäffera i niezależnie Kadego (quarto) oraz przyjmujących rękopis do berlińskich zbiorów (octavo) utrudniła ustalenie ciągłości proweniencyjnej.

\footnotetext{
${ }^{54}$ Odnotowany w: G.H. Schäffer, Bibliotheca Büloviana, t. 3, s. 1, poz. 10 jako: Augustini Omelie super sermone Domini in cena. Perg. - Cod. von $149 \mathrm{Bl}$.

55 G.H. Schäffer, Bibliotheca Büloviana, t. 3, s. 27, poz. 282.

${ }^{56}$ Inne kodeksy huysburskie w Berlinie trafiły do Königliche Bibliothek innymi drogami. Np. theol. lat. oct. 117, 118 i 119 mimo że obecne w katalogu sprzedaży Büloviany zostały zakupione w domu aukcyjnym T.O. Weigel w Dreźnie w 1880 roku, więc nie wiadomo ci się z nimi działo przez blisko 50 lat (zob. B. Braun-Niehr, Die theologischen lateinischen, s. 266).

${ }^{57}$ Prawie wszystkie wspomniane w tekście miejsca dzielą niewielkie odległości: z Huysburga do Halberstadt (10km), Beyernaumburga $(70 \mathrm{~km})$, Nordhausen $(60 \mathrm{~km})$, Kwerfurtu $(90 \mathrm{~km})$, czy wreszcie z Beyernaumburga do Nordhausen $(50 \mathrm{~km})$.

${ }^{58}$ Inicjał floralny „F” na f106v (Passio s. Victorini), inicjał floralny „R” na f55v.
} 


\section{Halberstadt i Magdeburg}

Powyższe ustalenia dotyczące historii pasjonału (i kodeksu) pozwalają w nowym świetle postawić pytanie o drogę, jaką przebył tekst „Żywota Pięciu Braci” od pierwopisu Brunona do zachowanego odpisu.

Próbując określić pochodzenie odkrytego przez siebie pasjonału, Reinhard Kade wskazał ostrożnie na Magdeburg, o czym więcej za chwilę, i za jego domysłem poszła cała późniejsza literatura przedmiotu. Zauważmy jednak od razu, że arcybiskupstwo św. Maurycego wraz ze swymi podległościami niekoniecznie zainteresowane było rozpowszechnianiem treści w jakikolwiek sposób stawiających je w negatywnym świetle, a takie przecież znajdujemy w tych rozdziałach „Żywota Pięciu Braci”, które relacjonują uwięzienie wysłanego do Rzymu eremity w Magdeburgu, zresztą wraz z poznańskim biskupem Ungerem, ${ }^{59}$. Na marginesie zauważmy, że w pismach Brunona obraz Magdeburga jest niejednoznaczny $-\mathrm{z}$ jednej strony jest to miejsce, gdzie nauki pobierał św. Wojciech oraz — niewiele później — sam Bruno, jest to Theutonum noua metropolis, z drugiej zaś nieodłączna grzeszność ludzka sprawia, że Magdeburg zamieszany zostaje już to w fatalne w skutkach zniesienie biskupstwa merseburskiego ${ }^{60}$, czy też we wspomniany już niechlubny epizod z uwięzieniem wysłanego w świętych sprawach poselstwa. Biorąc pod uwagę, jak daleko potrafią iść przeróbki utworów hagiograficznych pod piórem zręcznego „kopisty”, fragmenty te dałoby się stosunkowo łatwo złagodzić. Jednak wymowa dzieła Brunona mogła być niewygodna dla arcybiskupstwa magdeburskiego z powodów bardziej zasadniczych. Całe bowiem przedsięwzięcie misyjne Benedykta, Jana i Brunona było do pewnego stopnia sprzeczne z interesami Magdeburga. Misja miała objąć obszary, do których arcybiskupi magdeburscy mogli rościć sobie pretensje zwierzchnie ${ }^{61}$. Zupełnie inaczej mogło być w przypadku diecezji halbersztadzkiej, podległej metropolii w Moguncji. Samo powstanie arcybiskupstwa nad Łabą odbyło się kosztem biskupstwa w Halberstadt, które wskutek tego straciło blisko połowę powierzchni ${ }^{62}$. Upowszechnianie informacji o występkach sług św. Maurycego do pewnego stopnia cieszyć mogło duchownych z kręgu katedry św. Szczepana.

$\mathrm{Z}$ drugiej strony trzeba podkreślić, że w momencie spisywania huysburskiej kopii od powołania arcybiskupstwa magdeburskiego minęły dwa stulecia, toteż wskazane tu problemy straciły już na aktualności. Natomiast, co zauważył już Reinhard Kade, legendarz zawiera utwory na temat świętych, których relikwie sprowadzone zostały do Magdeburga w X i XI wieku. Zawarte w omawianym rękopisie przekazy kilku utworów poświęconych tym magdeburskim patronom, jak ostatnio podniósł Paul Bertrand, są jedynymi znanymi kopiami ${ }^{63}$. Czy zatem podstawa dla naszej kopii, albo nawet sam zachowany pasjonał mógł powstać w Magdeburgu? Jest to możliwe, ale należy zachować ostrożność we wnioskowaniu. Zawartość najdawniejszej części kodeksu wskazuje na Magdeburg, zwłaszcza za sprawą interpolacji dotyczących translacji relikwii do Magdeburga ${ }^{64}$.

59 VQF, rozdz. 21, w: MPH, t. 4, cz. 3, s. 72.

${ }^{60}$ M. Tomaszek, Brunon z Kwerfurtu i Otton II. Powstanie stowiańskie 983 roku jako grzech cesarza, Kwart. Hist., 109, 2002, z. 4, s. 5-23.

${ }^{61}$ Ostatnio M. Sosnowski: Co wiadomo o lokalizacji pustelni tzw. Pięciu Braci?, Rocz. Hist., 61, 2005, s. 26-28, gdzie również zebrana bibliografia.

${ }^{62}$ K. Bogumil, Das Bistum Halbertstadt, s. 26-27, 185.

${ }^{63}$ Passio S. Constantii, Passio S. Victorini, Passio S. Eusebii, Passio SS. Sisinnii, Diocletiani et Florentii. Zob. P. Bertand, Le trésor des reliques de Magdebourg sous les Ottoniens, w: Autour de saint Maurice. Actes du colloque Politique, société et construction identitaire, 29 sept-2 oct 2009, Besançon-Saint-Maurice, red. N. Brocard, F. Vannotti, A. Wagner, Saint-Maurice 2013, s. 188, p. 41.

${ }^{64}$ R. Kade, [Wstęp], w: MGH SS, t. 15, cz. 2, s. 711nn.; za nim W. Kętrzyński, [Wstęp], w: MPH, t. 6, Kraków 1893, s. 383; oraz J. Karwasińska, Wstęp, w: MPH s.n., t. 4, cz. 3, s. 14. Kętrzyński kodeksu nie widział i opacznie rozumie pewne sformułowania Kadego, bo wspomina o rzeczach, których rękopis nie zawiera, np. zapiskach „tu i ówdzie dodanych”, a Magdeburga dotyczących. Jak daleką drogę przeszły od tych czasów studia edytorskie świadczy uwaga Kętrzyńskiego, że „zniewoleni byliśmy korzystać z tekstu [...] który, za co firma Mon. Germ. hist. nam ręczy, może być uważanym za wierną kopię tekstu rękopiśmiennego". 


\section{Dlaczego Huysburg?}

Jakimi drogami utwór dostał się na teren Rzeszy? Nie mógł zostawić go tam Brunon, którego itinerarium zwyczajnie nie pozwala na wyprawy do Saksonii w ostatnim roku życia ${ }^{65}$. Wskazywać można raczej na osobę Wiperta, kapelana oślepionego w trakcie ostatniej wyprawy misyjnej, podczas której nasz hagiograf zginął ${ }^{66}$. Drogi szukać można też poprzez ród grafów Hassegau. Wszak sam ojciec hagiografa po śmierci swojego syna usunął się ze świata do klasztoru św. Michała w Lüneburgu ${ }^{67}$. O kontaktach tego klasztoru z opactwem w Huysburgu nic jednak nie wiemy. Nie oznacza to jednak, że brak pośrednich wskazówek na temat kontaktów między Huysburgiem a Kwerfurtem i rodem tamtejszych grafów.

Dyplomy huysburskie wskazujące na bezpośrednie kontakty klasztoru z grafami Kwerfurtu są nieliczne i stosunkowo późne ${ }^{68}$. Najstarszy z nich pochodzi z 2 połowy XIII w. Potwierdzone są natomiast wcześniejsze kontakty opactwa w Huysburgu z położonym na obszarze diecezji Halberstadt klasztorem Eilversdorf (Marienzell) pod Kwerfurtem. Świadkiem dokumentu wystawionego dla klasztoru w Huysburgu w 1197 r. przez Gardolfa, biskupa Halberstadt był m.in. Dytryk opat Eilversdorf (Eilwerdestorp) $^{69}$, zaś opat z Huysburga był świadkiem donacji biskupa Halberstadt na rzecz klasztoru w Eilversdorf w r. $1146^{70}$. W XV w., gdy klasztor w Huysburgu był poddany wpływom reformy bursfeldzkiej, w jego nekrologium pojawiają się imiona opatów klasztoru pod Kwerfurtem ${ }^{71}$. Klasztor w Eilversdorf założony po raz pierwszy w poł. XI w., ponownie ufundowany w 1157 r., a zniesiony w 1558 r., podobnie, jak huysburski, nosił wezwanie NMP i również należał of XV w. do kongregacji bursfeldzkiej ${ }^{72}$. O kultywowaniu w opactwie pamięci o naszym hagiografie świadczy wymienione w dokumencie fundacyjnym z 1157 r. drugie wezwanie klasztoru: ,s. Marie sanctique Brunonis episcopi et martiris" ${ }^{\prime 7}$. Data wystawienia dyplomu - 8 marca 1157 r. — o jeden dzień poprzedza rocznicę śmierci misjonarza. Co więcej, klasztor ten w XII w., czyli w okresie powstania omawianego tu rękopisu, był miejscem pochówku kwerfurckich grafów ${ }^{74}$. Z kolei przedstawiciele tego rodu pełnili w XII i XIII w. rozmaite funkcje kościelne i świeckie w Magdeburgu. Konrad I w 1. 1134-1142 był arcybiskupem magdeburskim, Wichmann II w 1. 1154-1192, czy jeszcze później Ruprecht z Kwerfurtu (1260-1266). Począwszy zaś od brata Konrada I, tj. od Burcharda II w 1136 aż do 1269 przedstawiciel rodu byli nieprzerwanie burgrafami Magdeburga ${ }^{75}$. Takie powiązania między kwerfuckimi Bruno-

\footnotetext{
${ }^{65}$ Czas i miejsce kompozycji VQF określa J. Karwasińska, Wstęp, w: MPH s.n., t. 4, cz. 3, s. 15-16. Nowe ujęcie itinerarium i chronologii twórczości Brunona oraz wykaz wcześniejszych prac zob. M. Sosnowski, Kilka uwag o chronologii życia i twórczości Brunona z Kwerfurtu, „Roczniki Historyczne” 82 (2016), w druku.

${ }^{66}$ M. Sosnowski, Anonimowa Passio s. Adalperti martiris (BHL 40) oraz Wiperta Historia de predicatione episcopi Brunonis (BHL 1471b) - komentarz, edycja, przekład, „Rocznik Biblioteki Narodowej”, 43, 2012, s. 33, 50 nn.; A. Rutkowska-Płachcińska, Pasje św. Wojciecha i Brunona z tzw. kodeksu z Tegernsee, St. Źródł., 40, 2002, s. 28. W tych opracowaniach również dawniejsza literatura przedmiotu. Jako pierwszy wysunął tę tezę Wojciech Kętrzyński.

${ }^{67}$ G. Althoff, Adels- und Königsfamilien im Spiegel ihrer Memorialüberlieferung. Studien zum Totengedenken der Billunger und Ottone. Bestandteil des Quellenwerkes Societas et Fraternitas, (Münstersche Mittelalter-Schriften, t. 47), München 1984, s. 418-419.

${ }^{68}$ Die Urkunden der Benedictiner-Abtei S. Mariae zu Huysburg, oprac. H. Beyer, F.L.B. von Medem, F. Wiggert, „Neue Mittheilungen aus dem Gebiet historisch-antiquarischer Forschungen”, 4, 1838, Heft 1, s. 1-76, nr 44, 57, $68,75$.

${ }^{69}$ Die Urkunden der Benedictiner-Abtei S. Mariae zu Huysburg, $\mathrm{nr} 22$, s. 16. Oryginał w Landeshauptarchiv Sachsen-Anhalt (Benutzungsort: Dessau), Z 1 (Anhaltisches Gesamtarchiv, Urkunden I), Nr. 74.

${ }^{70}$ Ch. Römer, Huysburg. Geschichte..., s. 632.

${ }^{71}$ Das Todtenbuch des Klosters Huisburg, wyd. E. Jacobs, „Harz-Verein für Geschichte und Altertumskunde”, 5, 1872, s. $274,308$.

${ }^{72}$ M. Lücke, Eilversdorf bei Querfurt, w: Germania Benedictina, t. 10, St. Ottilien 2012, s. 303-304.

73 Tamże, s. 304.

${ }^{74}$ M. Ludwig, Die vermeintlich Stiftsgründung des heiligen Brun von Querfurt. Kritische Überlegungen zu Datierung und Funktion der sogenannten ,fundacio ecclesie collegiate Quernfurtensis”, w: Brun von Querfurt. Lebenswelt, Tätigkeit, Wirkung, red. A. Sames, Querfurt 2010, s. 49, zwł. przyp. 56.

${ }^{75}$ B. Schwineköper, Konrad von Magdeburg, w: Neue Deutsche Biographie, t. 12, Berlin 1980, s. 509; tenże, Magdeburg, tamże, t. 15, Berlin 1987, s. 649 n; K. Uhlirz, Wichmann, w: Allgemeine Deutsche Biographie, t. 42, Leipzig 1897, s. 780-790; G. Wentz, B. Schwineköper, Das Erzbistum Magdeburg, (Germania Sacra, t. 1), t. 1, cz. 1, Berlin-New York 1972, s. 345.
} 
nidami a Magdeburgiem oraz Eilversdorf a Huysburgiem dostarczają aż nadto hipotetycznych dróg wędrówki dla naszego pasjonału oraz podstawy zawartej w nim kopii „Żywota Pięciu”.

Trafna wydaje się przy tym uwaga Kętrzyńskiego, że „rękopis Kadego jest prawdopodobnie kopią brulionu Brunona, który w oryginale lub kopii się dostał był do Magdeburga"76. Trudno tę tezę udowodnić, ale o tym, iż tekst Vita quinque fratrum jest nieukończony, może świadczyć dwukrotne zamieszczenie (zamierzone przeniesienie?) tych samych sformułowań $w$ różnych partiach tekstu ${ }^{77}$. Ów brulion trafić mógł do Kwerfurtu po śmierci Brunona, albo w Kwerfurcie zrobiono z tej roboczej wersji odpis.

Wedle relacji Gesta episcoporum Halberstadensium zachowanych w redakcji z przełomu XII i XIII w., opartych w tym miejscu być może na wcześniejszym, zaginionym dziś, przekazie, Brunon przed udaniem się wyprawę misyjną, zebrać miał „satis decenter collegium monachorum"78. To ostatnie łączono w literaturze z jeszcze późniejszą lokalną tradycją — zapisaną w Fundacio ecclesie collegiate Quernfurtensis ${ }^{79}$ - o założeniu przez misjonarza kolegium księży, które później przyjęło wezwanie św. Marii oraz samego Brunona ${ }^{80}$. W sensowność utożsamiania spraw opisywanych w tych relacjach powątpiewał już Heinrich Gisbert Voigt, a wspomniana wyżej opowieść o gromadzeniu księży de patrimonio suo przedstawiona jest w ścisłym połączeniu z udaniem się, wraz z osiemnastoma towarzyszami, na ostatnią wyprawę misyjną.

Być może więc albo brulion naszego hagiografa, zawierający bliską ukończenia wersję roboczą utworu, albo raczej sporządzony na jego podstawie odpis, trafił jako dar grafów kwerfurckich do Eilversdorf (Marienzell), klasztoru pod wezwaniem NMP i Brunona, będącego podówczas ich rodowym miejscem pochówku. W tym wypadku tekst Vita wywędrowałby z Kwerfurtu przez Eilversdorf do Huysburga albo bezpośrednio — w postaci naszego pasjonału — albo pośrednio — jako jego podstawa - do zaprzyjaźnionego klasztoru w Huysburgu. Wszystko to na obszarze diecezji halbersztadzkiej, w której na przełomie XII i XIII w. pamięć o Brunonie była na tyle silna, że poświęcono mu stosunkowo obszerny wpis w zachowanej redakcji Gesta Episcoporum Halberstadensium ${ }^{81}$. To że pasjonał zawiera żywoty świętych czczonych w Magdeburgu oraz opisy translacji świętych do tej metropolii, nie dziwi ze względu na pełnienie przez Brunonidów w tym mieście przeróżnych funkcji świeckich oraz, przede wszystkim, kościelnych z godnością arcybiskupią włącznie. Innymi słowy, przedstawiciele rodu grafów Kwerfurtu mogli posiadać teksty hagiograficzne dotyczące świętych czczonych w Magdeburgu, które — wraz z odpisem „Żywotu Pięciu Braci” — mogły zostać przekazane do Marienzell (i dalej do Huysburga).

\section{Podsumowanie}

Historia theol. lat. oct. 162 przedstawia się więc następująco. Pasjonał został skopiowany albo w Huysburgu albo w skryptorium (w diecezji halberstadzkiej lub magdeburskiej) mającym z Huysburgiem kontakty, a w każdym razie dość wcześnie - o czym świadczą dostrzegalne cechy późnej minuskuły karolińskiej w zapisce własnościowej - wszedł w posiadanie biblioteki tego opactwa. W XV w. został w tymże Huysburgu na nowo oprawiony, jako klocek wespół z dwoma innymi rękopisami, na co wskazują okładziny podobne do innych o proweniencji huysburskiej. W $1804 \mathrm{r}$. klasztor

\footnotetext{
${ }^{76}$ W. Kętrzyński, [Wstęp], w: MPH, t. 6, Kraków 1893, s. 385.

77 J. Karwasińska, [Wstęp], w: MPH s.n., t. 4, cz. 3., s. 17.

${ }_{78}$ Gesta Episcoporum Halberstadensium, wyd. L. Weiland, MGH SS, t. 23, Hannoverae 1874, s. 90.

79 Najnowsze studia krytyczne nad tekstem oraz edycję daje S. Pätzold, Die Querfurter Fundacio. Überlieferung und Edition, „Sachsen und Anhalt”, 22, 1999/2000, s. 135-145 oraz tenże, Die mittelalterliche Fundacio des Querfurter Kollegiatstiftes, tamże, 21, 1998, s. 37-65.

80 Sceptycznie i przekonująco zob. Mattias Ludwig, Die vermeintlich Stiftsgründung..., s. 39-60; zob. również tegoż, Brun und das Kollegiatstift auf Burg Querfurt, w: Der heilige Brun von Querfurt. Eine Reise ins Mittellater, Querfurt 2009, s. 195-202.

${ }^{81}$ K.-U. Jäschke, Die älteste Halberstädter Bischofschronik, (Mitteldeutsche Forschungen, t. 62, cz. 1), Köln-Wien 1970, s. 13. Zob. Gesta Episcoporum Halberstadensium, wyd. L. Weiland, MGH SS, t. 23 s. 89-90.
} 
został sekularyzowany i wkrótce potem jego dobra ruchome zostały wykupione, rozkradzione albo przekazane, jak wspomniano, do Uniwersytetu w Halle. Interesujący nas pasjonał wraz z co najmniej kilkoma innymi woluminami nabył asesor Friedrich Gottlieb Julius von Bülow z przeznaczeniem dla gromadzonych przez siebie zbiorów, tj. biblioteki na zamku w Beyernaumburgu. Trzydzieści lat później, a cztery lata po śmierci nabywcy, w 1835 r., Georg Heinrich Schäffer zatrudniony w roli kustosza wyprzedawanej biblioteki nadał kodeksowi foliację i opisał go w katalogu aukcyjnym, klasyfikując go wśród rękopisów in quarto. W jednym z wymienionych w katalogu domów aukcyjnych, będącym pośrednikiem szeroko zakrojonej wyprzedaży, zakupił rękopis drezdeński rytownik i profesor Anton Krüger. Najprawdopodobniej to on, lub jeden z jego spadkobierców, usunął kartę zawierającą notatkę katalogową Schäffera oraz — być może — inne zapiski własnościowe, których pozostałością są kwadratowe ubytki na kilka kartach. Te ostatnie mogły zostać również usunięte w Beyernaumburgu. W ten sposób trop historii kodeksu urwał się na prawie dwa stulecia. Od tego momentu historia kodeksu jest znana, ale dla porządku wymieńmy Reinharda Kade, odkrywcę tzw. „Żywota Pięciu Braci”, i jego ojca, Ottona Kade, jako kolejnych po swym krewnym Krügerze właścicieli. W 1899 r. znalezisko przekazane zostało, darem Reinharda Kade, do zbiorów Biblioteki Królewskiej Prus pod nr. akcesji 1899, 76. Kodeksowi, mimo nietypowego wymiaru, nadano sygnaturę stawiającą go wśród „ósemek”, tj. theol. lat. oct. 162, co bardzo utrudniło późniejsze ustalenie proweniencji. W trakcie II wojny światowej kodeks, wraz z resztą zbiorów, ewakuowano do Marburga (Westdeutsche Bibliothek), skąd został wypożyczony przez Bibliotekę Narodową, gdzie dla potrzeb edycji Jadwigi Karwasińskiej studium inicjałów przeprowadziła Krystyna Białoskórska ${ }^{82}$. Po zjednoczeniu Niemiec w 1990 r. pasjonał z Marburga wrócił w swoje poprzednie miejsce, do Biblioteki Państwowej w Berlinie.

Oczywiście przedstawiona wersja wydarzeń może być, choć jedynie w pewnym zakresie, modyfikowana. Dopóki nie dysponujemy dokumentami nabywcy (von Bülow), nie mamy pewności, że kodeks nie został zagrabiony w XVI w. i nie trafił w międzyczasie do zbiorów innej biblioteki. Ponieważ jednak prawie wszystkie rękopisy berlińskie z Huysburga, jak wskazują zapiski i foliacje Schäffera, również przeszły przez ręce von Bülow, wydaje się bardziej prawdopodobne, że zostały nabyte razem bezpośrednio z naszego klasztoru. Nie wiemy też, czy pasjonał spisany został w Huysburgu, czy tylko trafił do tego klasztoru dość wcześnie po spisaniu. Nie możemy również wyjść poza domysły na temat pochodzenia podstawy huysburskiej kopii (Kwerfurt, Eilversdorf/Marienzell, Magdeburg etc.). Pozostaje wyrazić nadzieje, że kwerendy archiwalne i biblioteczne naprowadzą na dalsze obiecujące tropy.

\section{Addenda: Zaginiony rękopis z Ebrach (Nepomuk)}

W dotychczasowej literaturze przedmiotu na temat tradycji rękopiśmiennej „Żywota Pięciu Braci” pojawiał się bawarski Ebrach, pierwszy cysterski klasztor na wschód od Renu, założony w 1127 r. jako filia opactwa Morimond ${ }^{83}$. Z opactwem tym starał się powiązać historię naszego kodeksu Georg Waitz $^{84}$, potem zaś zastanawiał się nad takim związkiem ksiądz Walerian Meysztowicz ${ }^{85}$. Emigracyjny historyk starając się rozświetlić cienie, w których przez stulecia spoczywał kodeks wskazał na zapiskę katalogową opactwa Ebrach, wymieniającą tekst zatytułowany Vita S. Benedicti et sociorum eius monach. in Polonia sub Henrico imperatore, qui post Ottonem III. rexit imperium ${ }^{86}$. Zastanawiał się nad powodami, dla których zapiska przybrała taką akurat formę i doszedł do wniosku, że ten zaginiony w XIX w. legendarz zawierać musiał żywot tzw. Pięciu Braci w wersji Kosmasa (BHL

\footnotetext{
${ }^{82}$ J. Karwasińska, Wstęp, w: MPH s.n., t. 4, cz. 3, s. 14, p. 21.

83 A. Wendehorst, Ebrach, w: Lexikon des Mittelalters, t. 3, szp. 1530.

${ }^{84}$ R. Kade, [Wstęp], w: MGH SS 15/2, s. 709, p. 3. Sam wstęp jest, podobnie jak wydanie, oczywiście autorstwa R. Kade, ale cytowany przypis to ingerencja redaktora tomu.

${ }^{85}$ W. Meysztowicz. La Vocation Monastique d'Otton III, s. 53.

${ }^{86}$ F.A. Reuß, Kurzer Abriß einer Geschichte der Bücher- und insbesondere Handschriften-Sammlungen im vormaligen Hochstifte Würzburg, „Serapeum”, 6/11, 1845, s. 185, poz. 69.
} 
1148; inc. Temporibus Henrici imperatoris qui post Ottonem), który wobec tego nie mógł być podstawą dla naszej kopii. Przychyliła się do tego również Jadwiga Karwasińska ${ }^{87}$, ale wobec zaginięcia rękopisu wnioskować można było jedynie na podstawie brzmienia tytułu w katalogu. Dziś dzięki najnowszemu drukowanemu katalogowi rękopisów z Ebrach trop ten trzeba rzeczywiście porzucić: dwunastowieczny legendarz odnalazł się i przechowywany jest obecnie w Bibliotece Uniwersytetu w Würzburgu. Pochodzić ma z Czech, z będącego filią Ebrach i zniszczonego w trakcie wojen husyckich klasztoru Nepomuk (w Kraju Pilzneńskim), i zawiera właśnie hagiograficzny wyimek z kroniki Kosmasa ${ }^{88}$. Swego czasu podstawę dla wersji praskiego kronikarza chciał widzieć Wojciech Kętrzyński w jakimś zaginionym żywocie tzw. Pięciu Braci, przywiezionym z Polski przez Brzetysława w latach trzydziestych XI w. Bardzo krytycznie odniosła się tej propozycji Jadwiga Karwasińska ${ }^{89}$, zaś Meysztowicz przeciwnie, domyślał się, że rękopis z Ebrach mógł stanowić podstawę dla epitome Kosmasa. Obecnie, dzięki wspomnianemu katalogowi, wiadomo już z całą pewnością, że kolejność zapożyczenia była odwrotna (czyli są to wyimki z kroniki praskiego dziekana, a nie kopia zaginionego źródła Kosmasa) niż ta proponowana przez Kętrzyńskiego i Meysztowicza, w przypadku tak tego rękopisu jak i szeregu innych ${ }^{90}$.

\section{The origin and history of passionale theol. lat. oct. 162 (Staatsbibliothek Berlin)}

Summary: Codex theol. lat. oct. 162 (Staatsbibliothek Berlin) plays an important role in Polish medieval studies due to its containing the sole witness of Vita Quinque Fratrum (BHL 1147) by Bruno of Querfurt. The article traces history of the codex from the origin until its discovery in the family library of Reinhard Kade, the first editor of VQF. The oldest part of the codex is a passionale (12/13th cent.), which was written at (or at least very early belonged to) the Benedictine monastery in Huysburg. In the 15th century - still in Huysburg it was bound together with two later unrelated manuscripts to form the current composite codex. During the secularization of the monastery at the beginning of the 19th century it came into possession of Friedrich Gottlieb Julius von Bülow (1760-1831), an assessor and book collector. After von Bülow's death his collection was put up at auction, the printed catalogue of which lists our manuscript. The codex was bought by Kade's paternal grandfather, Anton Krüger of Dresden a noted engraver. The rest of manuscript's history is well known.

The second part of the article examines a couple of hypothetical routes, through which the source copy for our witness (i.e. a very early copy or even Bruno's draft) or the witness itself could have been transferred to Huysburg, by tracing both direct and indirect connections of Querfurt counts and the monastery. Those hypothetical routes from Querfurt (Eilversdorf monastery?) to Huysburg — both in the diocese of Halberstadt - also try to make sense of the apparent interest that the passionale compiler had taken in Magdeburg.

A brief addendum discusses the implications of the re-discovery of a codex from Ebrach, previously considered lost, that was suspected by G. Waitz to be identical with our witness or, by W. Kętrzyński and W. Meysztowicz, to be a source for Cosmas' of Prague version of Five Brothers text. Late in the publishing process the author became aware the new description of theol. lat. oct. 162 (Beate Braun-Niehr, Manuscripta Mediaevalia database: <http://www.manuscripta-mediaevalia.de/dokumente/html/obj31101702> [access: 29.09.2016]. This new description independently and concisely provides some of the article's findings (ownership note from Huysburg, auction catalogue of „Bibliotheca Büloviana”, lost codex of EbrachNepomuk). Still available is the previous catalogue description, which was known to the author in February 2014, during the autopsy of Huysburg codices in Berlin <http://www.manuscripta-mediaevalia.de/ dokumente/html/obj90432270,T> [access: 29.09.2016].

\footnotetext{
87 J. Karwasińska: Wstęp, w: MPH s.n., t. 4, cz. 3, s. 11, p. 19.

88 Opatrzony sygn. M. p. th. q. 46. Zob. Die Handschriften der Zisterzienserabtei Ebrach, oprac. H. Thurn, Würzburg 1970, s. 77. Inna, piętnastowieczna, kopia znajduje się w opactwie benedyktynów w Melku (sygn. Cod. 16; dawniej: 677 oraz M 7).

89 J. Karwasińska: Wstęp, MPH s.n., t. 4, cz. 3, s. 10, p. 16.

90 Świadectwa rękopiśmienne tych wyciągów z Kosmasa, pochodzące z Czech, Bawarii i państwa Zakonu Krzyżackiego, wymienia Karwasińska, Wstęp, MPH s.n., t. 4, cz. 3, s. 11, p. 19.
} 
Nota o Autorze: Miło s z S o s n ow ski, ur. 1980. Absolwent Wydziału Historycznego UAM (2005), tam również doktorat (2010) poświęcony najdawniejszym żywotom i pasjom św. Wojciecha. Stypendysta programów Erasmus (Groningen), KBN (doktorat), Garstka Polish-American Fellowship (Notre Dame, IN), Nagrody MNiSW dla Młodych Naukowców oraz, obecnie, „Fuga” NCN. Zainteresowania badawcze skupione wokół hagiografii, kodykologii, paleografii łacińskiej, łaciny średniowiecznej i edytorstwa. Autor nowej edycji tzw. Pasji z Tegernsee i Relacji Wiperta, pracuje nad nową edycją dzieł zebranych Brunona z Kwerfurtu.

Author: Miłos z S o s n ow sk i, born 1980. Graduate of the Faculty of History at the Adam Mickiewicz University (2005), where in 2010 he also received a Ph.D. degree for a dissertation on the oldest vitae and passiones of St. Adalbert of Prague. Scholarship holder - Erasmus (Groningen), State Committee for Scientific Research (Ph.D.), and the Garstka Polish-American Research Fellowship (Notre Dame, Indiana), winner of the Award of the Ministry of Science and Higher Education for Young Scholars post-doctoral intern at the Univeristy of Warsaw through „Fuga” programme of the Polish National Science Centre. Interested in hagiography, codicology, Latin palaeography, mediaeval Latin and editorship. Author of a new edition of the so-called Passion from Tegernsee and the account by Wipertus; currently working on a new critical edition of the collected works of Bruno of Querfurt.

\section{Bibliografia}

Rękopisy

Staatsbibliothek Berlin, sygn.: theol. lat. oct. 162; lat. fol. 926; lat. oct. 364; lat. oct. 364; theol. lat oct. 117; theol. lat. fol. 499; theol. lat. fol. 501; theol. lat. fol. 661; theol. lat. oct. 118; theol. lat. quart. 238

Źródła drukowane

Der ,Chronicon Hujesburgense’, wyd. O. Menzel, „Studien und Mitteilungen zur Geschichte des Benediktinerordens und seiner Zweige", 52, 1934.

Gesta Episcoporum Halberstadensium, wyd. L. Weiland, MGH SS, t. 23, Hannoverae 1874.

Das Todtenbuch des Klosters Huisburg, wyd. E. Jacobs, „Harz-Verein für Geschichte und Altertumskunde”, 5, 1872.

Die Urkunden der Benedictiner-Abtei S. Mariae zu Huysburg, oprac. H. Beyer, F.L.B. von Medem, F. Wiggert, „Neue Mittheilungen aus dem Gebiet historisch-antiquarischer Forschungen”, 4, 1838, Heft 1.

Vita Quinque Fratrum Eremitarum, w: MPH s.n., t. 4, cz. 3, wyd. J. Karwasińska, Warszawa 1973.

Opracowania

Althoff G., Adels- und Königsfamilien im Spiegel ihrer Memorialüberlieferung. Studien zum Totengedenken der Billunger und Ottone. Bestandteil des Quellenwerkes Societas et Fraternitas, (Münstersche Mittelalter-Schriften, t. 47), München 1984.

Bertand P., Le trésor des reliques de Magdebourg sous les Ottoniens, w: Autour de saint Maurice. Actes du colloque Politique, société et construction identitaire, 29 sept-2 oct 2009, Besançon-Saint-Maurice, red. N. Brocard, F. Vannotti, A. Wagner, Saint-Maurice 2013.

Blaschke K., Huysburg, w: Lexikon des Mittelalters, t. 5.

Bogumil K., Das Bistum Halberstadt im 12. Jahrhundert. Studien zur Reichs- und Reformpolitik des Bischofs Reinhard und zum Wirken der Augustiner-Chorherren, (Mitteldeutsche Forschungen, t. 69) Köln 1972.

Braun-Niehr B., Die theologischen lateinischen Handschriften in octavo der Staatsbibliothek zu Berlin Preussischer Kulturbesitz, t. 1: Ms. theol. lat. oct. 66-125, (Staatsbibliothek zu Berlin Preußischer Kulturbesitz. Kataloge der Handschriftenabteilung, Erste Reihe t. 3, cz. 1), Wiesbaden 2007.

Cohen-Mushlin A., Scriptoria in Medieval Saxony. St. Pancras in Hamersleben, Wiesbaden 2004.

Cottin M., Die Lebenswelt Bruns von Querfurt im Spiegel zeitgenössischer Urkunden, w: Der Heilige Brun von Querfurt. Eine Reise ins Mittelalter. Begleitband zur Sonderaustellung, red. J. Rudolph, M. Kühnel, Querfurt 2009.

Eckart Th., Geschichte des Klosters Huysburg bei Halbertstadt, (Geschichte der Burgen und Klöster des Harzes, t. 6), wyd. 2, Leipzig 1905.

Erdmann H., Kade, Otto, w: Neue Deutsche Biographie, t. 10, Berlin 1974.

Europas Mitte im 1000. Austellungskatalog, red. A. Wieczorek, H.-M. Hinz, Stuttgart 2000. 
van Ess C., Kurze Geschichte der ehemaligen Benedictinerabtei Huysburg: nebst einem Gemälde derselben und ihrer Umgebungen, Halberstadt 1810.

Fingernagel A., Die illuminierten lateinischen Handschriften süd-, west- und nordeuropäischer Provenienz der Staatsbibliothek zu Berlin Preussischer Kulturbesitz, t. 4: 12. Jahrhundert, cz. 1. Text. Mit Nachträgen zu Bd. 1, Staatsbibliothek Preussischer Kulturbesitz. Kataloge der Handschriftenabteilung 3, Illuminierte Handschriften; 2/1-2), Wiesbaden 1991.

Die Handschriften der Zisterzienserabtei Ebrach, oprac. H. Thurn, Würzburg 1970.

Hoffmann H., Handschriftenfunde, (MGH Studien und Texte, t. 18), Hannover 1997.

Jäschke K.-U., Die älteste Halberstädter Bischofschronik, (Mitteldeutsche Forschungen, t. 62, cz. 1), Köln-Wien 1970.

Kade R., Ein Augensegen, „Neues Archiv”, 10, 1885.

Kade R., Beschreibung eines Legendars, „Neues Archiv”, 8, 1883.

Kade R., De Brunonis Querfurtensis vita quinque fratrum Poloniae nuper reperta, Lipsiae 1883.

Kade R., [Wstęp], w: MGH SS, t. 15, cz. 2.

Karwasińska J., Wstęp, w: MPH s.n, t. 4, cz. 3.

Kętrzyński W., [Wstęp], w: MPH, t. 6, Kraków 1893.

Krämer S., Mittelalterliche Bibliothekskataloge Deutschlands und der Schweiz. Ergänzungsband I: Handschriftenerbe des deutschen Mittelalters, t. 1: Aachen-Kochel, München 1989.

Krüger Anton, w: Pierer's Universal-Lexikon, t. 9, Altenburg 1860.

Krüger Anton, w: Allgemeine Deutsche Biographie, t. 17, Leipzig 1883.

Krusch B., [Wstęp], w: Vita Columbani, wyd. B. Krusch, w: MGH SSrM, t. 4., Hannoverae et Lipsiae 1902.

Krusch B., [Wstęp], w: Passio Kiliani, w: MGH SSrM 5, wyd. B. Krusch, Hannoverae et Lipsiae 1910.

Krusch B., [Wstęp], w: Vita Columbani, w: MGH SSrG, t. 37, wyd. B. Krusch, Hannoverae et Lipsiae 1905.

Lücke M., Eilversdorf bei Querfurt, w: Germania Benedictina, t. 10, St. Ottilien 2012.

Ludwig M., Die vermeintlich Stiftsgründung des heiligen Brun von Querfurt. Kritische Überlegungen zu Datierung und Funktion der sogenannten ,fundacio ecclesie collegiate Quernfurtensis”, w: Brun von Querfurt. Lebenswelt, Tätigkeit, Wirkung, red. A. Sames, Querfurt 2010.

McCormick Gatch M., The Book Collections and the Library of Leander van Ess, w: 'so precious a foundation' the Library of Leander Van Ess at the Burke Library of Union Theological Seminary in the City of New York, red. tenże, New York 1996

Meysztowicz W., La vocation monastique d'Otton III, „Antemurale”, 4, 1958.

Milde W., Huysburg. Bibliotheksgeschichte, w: Die Mönchsklöster der Benediktiner in Mecklenburg-Vorpommern, Sachsen-Anhalt, Thüringen und Sachsen, red. Ch. Römer, M. Lücke, (Germania Benedictina, t. 9, cz. 1-2), Sankt Ottilien 2012.

Pätzold S., Brun und das Kollegiatstift auf Burg Querfurt, w: Der heilige Brun von Querfurt. Eine Reise ins Mittellater, Querfurt 2009.

Pätzold S., Die Querfurter Fundacio. Überlieferung und Edition, "Sachsen und Anhalt”, 22, 1999/2000.

Pötschke D., Kloster Ilsenburg — Geschichte, Architektur, Bibliothek, (Harz-Forschungen, t. 19), Berlin 2004.

Répertoire topo-bibliographique des abbayes et prieurés, t. 1: A-L, oprac. L.-H. Cottineau OSB, Mâcon 1936.

Reuß F. A., Kurzer Abriß einer Geschichte der Bücher- und insbesondere Handschriften-Sammlungen im vormaligen Hochstifte Würzburg, ,Serapeum”, 6/11, 1845.

Römer Ch., Dylong A., Henke P., Pfeil A., Huysburg. Geschichte, w: Die Mönchsklöster der Benediktiner in Mecklenburg-Vorpommern, Sachsen-Anhalt, Thüringen und Sachsen, red. Ch. Römer, M. Lücke, (Germania Benedictina, t. 9, cz. 1-2), Sankt Ottilien 2012.

Rutkowska-Płachcińska A., Pasje św. Wojciecha i Brunona z tzw. kodeksu z Tegernsee, „Studia Źródłoznawcze", 40, 2002.

Sammlung und Verzeichniss handscriftlicher [sic] Bücher aus dem VIII. IX. X. XI. XII. XIII. XIV, etc. Jahrhundert, bestehend aus 171 Bänden auf Pergament, 19 theils auf Pergament theils auf Papier, und 190 auf Papier. Nebst einer Sammlung von alten Holzschnitten und kleinen Gemälden mit Vergoldung, die leider! aus alten Pergament-Handschriften ausgeschnitten sind, welche besitzt Leander van Ess, Theol. Doctor, vorhin Professor und Pfarrer in Marburg, Darmstadt 1823.

Schäffer G.H., Bibliotheca Buloviana, t. 1, Sangerhausen 1834.

Schieffer Th., Burchard II. (Bucco), w: Lexikon des Mittelalters, t. 2.

Schwineköper B., Konrad von Magdeburg, w: Neue Deutsche Biographie, t. 12, Berlin 1980. 
Schwineköper B., Magdeburg, w: Neue Deutsche Biographie, t. 15, Berlin 1987

Statistisches Handbuch der deutschen Gymnasien, für das Jahr 1836, red. C.E. Brauns, A. Theobald, t. 1, Kassel 1837.

Sosnowski M., Anonimowa Passio s. Adalperti martiris (BHL 40) oraz Wiperta Historia de predicatione episcopi Brunonis (BHL 1471b) - komentarz, edycja, przekład, „Rocznik Biblioteki Narodowej”, 43, 2012.

Sosnowski M., Co wiadomo o lokalizacji pustelni tzw. Pięciu Braci?, Rocz. Hist., 61, 2005.

Tomaszek M., Brunon z Kwerfurtu i Otton II. Powstanie stowiańskie 983 roku jako grzech cesarza, Kwart. Hist., 109, 2002, z. 4.

Uhlirz K., Wichmann, w: Allgemeine Deutsche Biographie, t. 42, Leipzig 1897.

Wentz G., Schwineköper B., Das Erzbistum Magdeburg, (Germania Sacra, t. 1), t. 1, cz. 1, Berlin-New York 1972.

Ziegler W., Die Bursfelder Kongregation, w: Die Reformverbände und Kongregationen der Benediktiner im deutschen Sprachraum, (Germania Benedictina, t. 1), U. Faust, F. Quarthal, St. Ottilien 1999. 